\title{
STUDY PROGRAMS OF TRAINING TEACHERS OF INFORMATICS IN THE CZECH REPUBLIC
}

\author{
Jan BERKI
}

\begin{abstract}
Accreditations of so-called long-master's programs (5 years) draw to an end of their force in the Czech Republic. Training teachers of Informatics (Computer Science) was also divided into two levels. Bachelor's programs (3 years) bear the name e. g. Informatics (Computer Science) in Education. Master's programs (2 years) are named Teaching of Informatics (Computer Science). They are differentiated the master's programs of teaching for lower-secondary school from teaching for upper-secondary (high) schools at some universities. This article provides a comparison of the subjects-composition of these study programs at Czech universities. The subjects are grouped by their content into thematic sections: mathematics, programming, systems, didactics, publishing and hardware. Their incorporation is represented for one thing by number of credits and for another by number of lessons a week. Syllabi of all Czech universities, that have accredited mentioned programs, were included in this survey. The submission refers about eleven faculties. Data were collected from twenty-two study plans.
\end{abstract}

Key words: teacher training, Informatics, syllabi, Czech universities.

\section{Introduction}

Information and communication technology, or Informatics as an area has gained its place in the curricula of both primary and secondary education institutions. With a few exceptions, Czech universities train future teachers in structured degree programs. One exception are degrees in primary education, which remain 5 -year masters programs. It is then possible to ask, how does the 2-degree training prepare teachers for this particular area. Teacher education in Informatics has a certain tradition in Czech lands. We can assume it comes from the past where the focus was largely aimed at programming and technological aspects of computing. We can further assume, that most Informatics teachers had earned their degree in technical training and later underwent further pedagogic education.

This article does not concern itself with comparison of the so-called "long" and structured study programs. The main objective is to compare accredited programs aimed at teacher education in Informatics and describe significant differences amongst them while taking into account the subject composition of their respective curricula. Are there distinctively different approaches to Informatics teacher education in Czech universities or not?

\section{Methodology}

The article presents results of a multiple-case study. As the main methodological tool, the conceptual content analysis was used [1]. Several fundamental concepts were established and later researched. This involved resorting to similar resources in electronic or printed forms of publicly available curricula of study programs in question. All findings were compiled into tables and compared.

\subsection{The sample}

The sample included all universities in the Czech republic, which, according to the publicly available database of the Ministry of Education, offer accredited programs in education of future Informatics teachers [2]. Disqualified from the sample were programs where the accreditation expired before the date on which the sample was determined. Where two lines in a database would differ only in the accreditation dates, earlier records were marked as redundant and the sample included the most up-to-date record. For the purposes of study, full-time study was considered as equivalent to its combined form. Where the programme had been accredited for both forms of study, only the full-time version was included in the sample. Programmes that were accredited until 2012 are included in the sample based on the assumption of being successfully reaccredited. Since teachers in the Czech republic study approbation for two subjects, the sample considers only programs that allow for the option of Informatics. In order to fulfill the compulsory requirement for sampling, study programs curricula and subject syllabi had to be available online. The total sample consisted of 22 study programmes from 11 faculties of 9 universities: 
- Charles University in Prague (UK) - Faculty of Education (PedF), Faculty of Mathematics and Physics (MFF)

- Jan Evangelista Purkyně University in Ústí nad Labem (UJEP) - Faculty of Science (PrF)

- Masaryk University in Brno (MU) - Faculty of Education (PedF)

- Technical University of Liberec (TUL) Faculty of Science, Humanities and Education (FPHP)

- Tomas Bata University in Zlín (UTB) Faculty of Applied Informatics (FAI)

- University of Hradec Králové (UHK) Faculty of Education (PedF)

- University of Ostrava (OU) - Faculty of Science (PrF)

- University of South Bohemia (JU) - Faculty of Education (PedF), Faculty of Science (PrF)

- University of West Bohemia (ZCU) - Faculty of Education (PedF)

The sample is composed of 9 bachelor (B) degree and 13 masters $(\mathrm{M})$ degree programmes. As indicated by Table 1, 7 faculties hold accreditation for both degrees.

Table 1: Overview of accredited programmes

\begin{tabular}{|c|c|c|c|}
\hline Uni. & Fac. & & Name of the study programme \\
\hline \multirow{4}{*}{ UK } & \multirow[b]{2}{*}{ PedF } & $\mathrm{B}$ & IT in Education [9] \\
\hline & & M & $\begin{array}{l}\text { Teacher Training for Basic and } \\
\text { Upper-Secondary Schools - ICT } \\
\text { [11] }\end{array}$ \\
\hline & \multirow[b]{2}{*}{ MFF } & B & Informatics in Education [6] \\
\hline & & M & $\begin{array}{l}\text { Teacher Training in Informatics } \\
\text { for Upper-Secondary Schools [7] }\end{array}$ \\
\hline UJEP & $\operatorname{PrF}$ & B & Informatics in Education [15] \\
\hline MU & PedF & M & $\begin{array}{l}\text { Teacher Training in Informatics } \\
\text { for Basic Schools [13] }\end{array}$ \\
\hline \multirow{3}{*}{ TUL } & \multirow{3}{*}{ FPHP } & $\mathrm{B}$ & Informatics in Education [16] \\
\hline & & M & $\begin{array}{l}\text { Teacher Training in Informatics } \\
\text { for Lower-Secondary Schools [22] }\end{array}$ \\
\hline & & M & $\begin{array}{l}\text { Teacher Training in Informatics } \\
\text { for Upper-Secondary Schools [23] }\end{array}$ \\
\hline UTB & FAI & M & $\begin{array}{l}\text { IT Education for Secondary } \\
\text { Schools [19] }\end{array}$ \\
\hline \multirow{3}{*}{ UHK } & \multirow{3}{*}{ PedF } & B & Informatics in Education [3] \\
\hline & & M & $\begin{array}{l}\text { Teacher Training for Lower- } \\
\text { Secondary Schools - Informatics } \\
\text { [4] }\end{array}$ \\
\hline & & M & $\begin{array}{l}\text { Teacher Training for Upper- } \\
\text { Secondary Schools - Informatics } \\
\text { [5] }\end{array}$ \\
\hline \multirow{3}{*}{$\mathrm{OU}$} & \multirow{3}{*}{ PrF } & B & Informatics [8] \\
\hline & & M & $\begin{array}{l}\text { Teacher Training in Informatics } \\
\text { for Basic Schools [10] }\end{array}$ \\
\hline & & M & $\begin{array}{l}\text { Teacher Training in Informatics } \\
\text { for Upper-Secondary Schools [12] }\end{array}$ \\
\hline
\end{tabular}

\begin{tabular}{|c|c|c|c|}
\hline Uni. & Fac. & & Name of the study programme \\
\hline \multirow{3}{*}{$\mathrm{JU}$} & \multirow{2}{*}{ PedF } & B & IT in Education [18] \\
\hline & & $\mathrm{M}$ & Teacher Training in IT [24] \\
\hline & $\operatorname{PrF}$ & B & $\begin{array}{l}\text { Informatics for Future Teachers } \\
\text { [17] }\end{array}$ \\
\hline \multirow{3}{*}{ ZCU } & \multirow{3}{*}{ PedF } & B & IT in Education [20] \\
\hline & & M & $\begin{array}{l}\text { BS Teacher Training in Computer } \\
\text { Technology [14] }\end{array}$ \\
\hline & & $\mathrm{M}$ & $\begin{array}{l}\text { SS Teacher Training in Computer } \\
\text { Technology [21] }\end{array}$ \\
\hline
\end{tabular}

\subsection{Subject Groups}

For the sake of the composition analysis, subjects from each study curriculum were assigned to one of the categories defined bellow:

- Mathematics (MAT) - Includes subjects aimed at mathematics as such and subjects with direct relation to mathematics (for example: complexity, algorithmic computability, etc.)

- Algorithms (ALG) - Serves as an umbrella category for the education of programming languages (C, Pascal, Java etc.), formal languages, grammars and automata.

- Systems (SYS) - Information, operating and database system make up a category of subjects that range include education of both practical use and deeper system knowledge.

- Publishing (PUB) - This category includes all subjects that aim to teach students to publish properly. Its identifying categories are multimedia, graphics, text processing, officesuites and Web pages (HTML).

- Computers (COM) - The penultimate category incorporates two components. First is the technological background of Informatics such as hardware, Von Neumann, computer network and physics. Secondly, it includes technological visions - the concept of artificial intelligence.

- Didactics (DID) - From the viewpoint of teacher education, this category is certainly interesting. It comprises of subjects aimed at didactics of education component, e-learning methodology, use of didactic techniques or production of learning tools.

Specialization subjects were not assigned to the categories based on merely on their names. Using syllabi, each subject was scrutinised and later assigned the appropriate category. Where the subject embraced concepts of several categories at once, it was placed into the most fitting one. This has resulted in a certain level 
of bias. To calculate the subject category representation ratio, following equation is used $\mu$ (category) $=\sum$ (credits of subjects in the category) $/ \sum$ (credits of study program).

The standard amount of credits in study plans is, abiding the ECTS label, 60 credits per academic year. This survey does not however include compulsorily elective subjects, elective subjects, subjects from the other approbation or those pertaining to the pedagogic part of the curriculum. Total sum for each study programme will therefore differ and for this reason the results presented in the following chapter are in percentages.

\section{Findings}

The following chapter presents the results of comparison for various types of university education. The Appendix contains a summary table that presents data in absolute values, not percentages. Zero values are marked by light grey, dark grey marks ratios over one-third in their respective category.

\subsection{Bachelors programmes}

Most degree names refer to both Informatics and Education alike.

Table 2: Category Representation Ration in study programme (bachelor)

\begin{tabular}{|l|c|c|c|c|c|c|}
\hline Uni. & MAT & $A L G$ & SYS & PUB & COM & DID \\
\hline PedF JU & 0,23 & 0,23 & 0,19 & 0,17 & 0,11 & 0,08 \\
\hline PrF JU & 0,20 & 0,28 & 0,25 & 0,07 & 0,21 & 0,00 \\
\hline FPHP TUL & 0,23 & 0,33 & 0,19 & 0,09 & 0,07 & 0,09 \\
\hline PrF UJEP & 0,11 & 0,29 & 0,17 & 0,18 & 0,22 & 0,03 \\
\hline PedF ZCU & 0,08 & 0,26 & 0,02 & 0,26 & 0,38 & 0,00 \\
\hline PedF UHK & 0,16 & 0,18 & 0,28 & 0,04 & 0,19 & 0,15 \\
\hline MFF UK & 0,15 & 0,57 & 0,22 & 0,00 & 0,07 & 0,00 \\
\hline PedF UK & 0,09 & 0,10 & 0,23 & 0,29 & 0,26 & 0,03 \\
\hline PrF OU & 0,27 & 0,35 & 0,27 & 0,00 & 0,12 & 0,00 \\
\hline average & 0,17 & 0,29 & 0,20 & 0,12 & 0,18 & 0,04 \\
\hline median & 0,16 & 0,28 & 0,22 & 0,09 & 0,19 & 0,03 \\
\hline
\end{tabular}

The last column of Table 2 indicates that Bachelor programmes place focus on the informatics aspect of future teachers' specialization. In a single case, the ratio of didactic subjects exceeds $10 \%$. In half of the cases, the didactics category has minimum or none representation. Most programmes however exhibit strong representation of algorithm and programming categories. In one case, this presents more than a half of all credits.
In none of the programmes was observed a differentiation greater than $5 \%$ between credit representation and full-time teaching.

\subsection{Masters programmes}

In contrast to Bachelors programmes, Masters programmes focus entirely on preparing future teachers of Informatics. At some universities we can find differentiated programmes for primary and lower-secondary as well as upper-secondary teachers. Table 3 demonstrates that the curriculum composition at TUL and ZCU varies depending on the level of target education level. However UHK and UO retain the same curricular structure and do not differentiate.

Table 3: Category Representation Ratios in study programme (master)

\begin{tabular}{|c|c|c|c|c|c|c|}
\hline Uni. & $M A T$ & $A L G$ & $S Y S$ & $P U B$ & $C O M$ & $D I D$ \\
\hline PedF JU ${ }^{1}$ & 0,00 & 0,00 & 0,00 & 0,00 & 0,48 & 0,52 \\
\hline FPHP TUL ${ }^{1}$ & 0,00 & 0,26 & 0,19 & 0,13 & 0,06 & 0,35 \\
\hline FPHP TUL $^{2}$ & 0,23 & 0,32 & 0,00 & 0,13 & 0,00 & 0,32 \\
\hline PedF ZCU ${ }^{3}$ & 0,00 & 0,07 & 0,18 & 0,07 & 0,04 & 0,64 \\
\hline $\mathrm{PedF}_{\mathrm{ZCU}}{ }^{2}$ & 0,14 & 0,21 & 0,17 & 0,00 & 0,03 & 0,45 \\
\hline PedF UHK ${ }^{1}$ & 0,00 & 0,00 & 0,00 & 0,22 & 0,14 & 0,64 \\
\hline PedF UHK ${ }^{2}$ & 0,00 & 0,00 & 0,00 & 0,22 & 0,14 & 0,64 \\
\hline MFF UK $^{2}$ & 0,17 & 0,00 & 0,00 & 0,21 & 0,00 & 0,62 \\
\hline PedF UK ${ }^{4}$ & 0,00 & 0,00 & 0,00 & 0,00 & 0,00 & 1,00 \\
\hline FAI UTB $^{2}$ & 0,00 & 0,09 & 0,27 & 0,12 & 0,24 & 0,27 \\
\hline PedF MU $^{2}$ & 0,00 & 0,30 & 0,27 & 0,06 & 0,30 & 0,06 \\
\hline $\mathrm{PrF} \mathrm{OU}^{2}$ & 0,00 & 0,30 & 0,00 & 0,00 & 0,00 & 0,70 \\
\hline $\mathrm{PrF} \mathrm{OU}^{2}$ & 0,00 & 0,30 & 0,00 & 0,00 & 0,00 & 0,70 \\
\hline average & 0,04 & 0,14 & 0,08 & 0,09 & 0,11 & 0,53 \\
\hline median & 0,00 & 0,09 & 0,00 & 0,07 & 0,04 & 0,62 \\
\hline
\end{tabular}

${ }^{1}$ ISCED $2,{ }^{2}$ ISCED $3,{ }^{3}$ ISCED $1+2,{ }^{4}$ ISCED $1+2+3$

The ration for individual categories has changed dramatically. It has seen a depreciation of Mathematics. In three-quarters of the cases is not represented in the study programme at all. The attitude toward programming is interesting. In about half of the cases programming takes up a whole quarter of the programme. On the other hand, the other half of the cases the ratios are very small or zero. Similar situation occurs with Systems, where they are omitted by roughly $50 \%$ of the researched programmes. Naturally, we observe increase in representation of didactic subjects.

By comparing the two previous tables we can establish a shift in curriculum structure between Bachelors and Masters degree. The JU divides attention between didactics and technological foundation. In the ISCED 2 aimed programme, TUL limits the category Mathematics and develops Didactics. The ISCED 3 programme at the same university cuts down on System 
oriented subjects. We can observe even more changes at the ZCU. Both programmes see the increase in the ratio of Systems and decline in Publishing and Computers. Further, Didactics is also reinforced significantly. The UHK programme is defined by a maximum omission in the first three categories. Aside from Didactics, Publishing is also appreciated. UK strengthens their Didactics most significantly of all universities on the Masters degree and eliminates dramatically all other categories. Similar situation can be observed at the OU, although Programming retains about one-third ratio.

The PedF MU indicated in the Computer category $13 \%$ higher credit representation to full-time teaching.

\subsection{Bachelors and Masters programmes}

Following table presents Credit Representation Ratios for both degrees of structured programmes.

Table 4: Credit Representation Ratios (Bachelor + Master)

\begin{tabular}{|c|c|c|c|c|c|c|}
\hline Uni. & $M A T$ & $A L G$ & SYS & $P U B$ & COM & DID \\
\hline PedF JU $^{1}$ & 0,16 & 0,16 & 0,13 & 0,12 & 0,22 & 0,21 \\
\hline FPHP TUL ${ }^{1}$ & 0,16 & 0,31 & 0,19 & 0,10 & 0,07 & 0,17 \\
\hline FPHP TUL ${ }^{2}$ & 0,23 & 0,33 & 0,13 & 0,10 & 0,05 & 0,16 \\
\hline PedF ZCU ${ }^{3}$ & 0,05 & 0,19 & 0,08 & 0,19 & 0,26 & 0,23 \\
\hline $\mathrm{PedF}_{\mathrm{ZCU}}{ }^{2}$ & 0,10 & 0,24 & 0,08 & 0,16 & 0,25 & 0,16 \\
\hline PedF UHK $^{1}$ & 0,11 & 0,12 & 0,18 & 0,11 & 0,17 & 0,32 \\
\hline PedF UHK ${ }^{2}$ & 0,11 & 0,12 & 0,18 & 0,11 & 0,17 & 0,32 \\
\hline MFF UK ${ }^{2}$ & 0,16 & 0,41 & 0,16 & 0,06 & 0,05 & 0,17 \\
\hline PedF UK ${ }^{4}$ & 0,07 & 0,08 & 0,18 & 0,22 & 0,20 & 0,25 \\
\hline $\mathrm{PrF} \mathrm{OU}^{2}$ & 0,19 & 0,33 & 0,19 & 0,00 & 0,08 & 0,19 \\
\hline $\mathrm{PrF} \mathrm{OU}^{2}$ & 0,19 & 0,33 & 0,19 & 0,00 & 0,08 & 0,19 \\
\hline average & 0,14 & 0,24 & 0,15 & 0,11 & 0,15 & 0,22 \\
\hline median & 0,16 & 0,24 & 0,18 & 0,11 & 0,17 & 0,19 \\
\hline
\end{tabular}

${ }^{1}$ ISCED $2,{ }^{2}$ ISCED $3,{ }^{3}$ ISCED $1+2,{ }^{4}$ ISCED $1+2+3$

With the exception of three cases, the ratios in individual categories are not extreme in any way. An interesting phenomenon is the absence of Publishing category in OU study programmes. MFF emphasizes the teaching of Algorithms and Programming.

In none of the programmes was observed a differentiation greater than $5 \%$ between the credit representation and full-time teaching.

\section{Discussion and Conclusion}

The structuring of tertiary study programmes has brought a more intense focus on informatics specialization on one hand and pedagogic specialization on the other. This study supports this thesis. Even though we are aware that there may be inaccuracies due to subjects overlapping individual categories, the research presented here draws a picture of curriculum composition with sufficient informative value. It is evident from the results, that the undergraduate training of informatics teachers reflects informatics as a scientific discipline. Algorithms are widely considered as the cornerstone of this discipline while they receive a little curricular attention at basic or secondary schools. More often, teaching tends to specialize in office-suites and publication of information. This brings about a rather curious situation in the Czech republic.

It could be said that the majority of subject taught in basic schools already reflect themself as scientific disciplines. On the other hand, the area corresponding to Informatics called ICT seems to default on this context. The question is, whether it should be the undergraduate degrees that should be adjusted to fit the reality. Should the curriculum composition be changed in favor of the Publish category? In the same manner, it could be said that more than $24 \%$ of skills and knowledge gained during university studies will never come to use when teaching. A similar reasoning could be employed in mathematical subjects and systems.

Future teachers ought to gain an insight into their field of expertise and be prepared for teaching subjects for which they are qualified. Do the Czech study programmes for teaching informatics reflect accurately both sides of the same coin? It is due to the conservativeness of Czech universities that specialized informatics topics remain in study plans. On the other hand, as a result of more progressive visions present in the Czech education system, the position of didactics within these plans is strengthening. A possible subsequent research could be an analysis of intended and executed teachings of didactic subjects.

\section{Bibliography}

[1] Content Analysis [online]. (C) 1993-2012 Colorado State University. [Cit. 2012-07-01]. Available from http://writing.colostate.edu/ guides/guide.cfm?guideid $=61$.

[2] Johánek, J. Akreditované studijni programy vysokých škol [online]. (C) 2006-2012 MSMT. [Cit. 2012-07-02]. Available (in Czech) from http://www.msmt.cz/ vzdelavani/akreditovanestudijni-programy-vysokych-skol-s-uvedenimkodu-studijnich-programu-a-oboru?lang=1.

[3] Study programme: Informatics in Education [online]. University of Hradec Králové. [Cit. 
2012-07-10]. Available (in Czech) from http://hades.uhk.cz/fispublic/Student/UcebniPlan. asp?StudOborID1=P-INB.

[4] Study programme: Teacher Training for Lower-Secondary Schools - Informatics [online]. University of Hradec Králové. [Cit. 2012-07-10]. Available (in Czech) from http://hades.uhk.cz/ fispublic/Student/UcebniPlan.asp?StudOborID1= P-NZS2IN.

[5] Study programme: Teacher Training for Upper-Secondary Schools - Informatics [online]. University of Hradec Králové. [Cit. 2012-07-10]. Available (in Czech) from http://hades.uhk.cz/ fispublic/Student/UcebniPlan.asp?StudOborID1= P-NSSKIN.

[6] Study Programmes of Faculty of Mathematics and Physics 2011/2012 for credits three-levels studying [online]. Faculty of Mathematics and Physics Charles University in Prague. pp. 87-93. [Cit. 2012-07-10]. Available (in Czech) from http://www.mff.cuni.cz/fakulta/tiskoviny/or_k1 1 12.pdf.

[7] Study Programmes of Faculty of Mathematics and Physics 2011/2012 for credits three-levels studying [online]. Faculty of Mathematics and Physics Charles University in Prague. pp. 158164. [Cit. 2012-07-10]. Available (in Czech) from http://www.mff.cuni.cz/fakulta/tiskoviny/ or_k1112.pdf.

[8] Study programme of Informatics [online]. University of Ostrava. [Cit. 2012-07-12]. Available (in Czech) from http://stag.osu.cz/ prohlizeni/pg\$_prohlizeni.stpl? pl=9112.

[9] Study programme of IT in Education [online]. PedF Karolínka, Faculty of Education Charles University in Prague. [Cit. 2012-07-11]. Available (in Czech) from http://userweb.pedf.cuni.cz/kch/karolinka/2011/ OB2IT10.html.

[10] Study programme of Teacher Training in Informatics for Basic Schools [online]. University of Ostrava. [Cit. 2012-07-12]. Available (in Czech) from http://stag.osu.cz/ prohlizeni/pg\$_prohlizeni.stpl?pl=9177.

[11] Study programme of Teacher Training for Basic and Upper-Secondary Schools - ICT [online]. PedF Karolínka, Faculty of Education Charles University in Prague. [Cit. 2012-07-11]. Available (in Czech) from http://userweb.pedf.cuni.cz/kch/karolinka/2011/ ON2IT09.html.

[12] Study programme of Teacher Training in Informatics for Upper-Secondary Schools [online]. University of Ostrava. [Cit. 2012-07-
12]. Available (in Czech) from http://stag.osu.cz/ prohlizeni/pg\$_prohlizeni.stpl?pl=9168.

[13] Teacher Training in Informatics for Basic Schools [online]. Masaryk University in Brno. [Cit. 2012-07-11]. Available (in Czech) from http://is.muni.cz/do/ped/stud/studk/2012_2013/ prez/IN2_NP.html.

[14] Visual study programme of BS Teacher Training in Computer Technology [online]. Version 1, year 2012. University of West Bohemia in Plzeň. [Cit. 2012-07-10]. Available (in English) from https://portal.zcu.cz/stag?urlid= prohlizeni-browser-vizualizace\&browserFakulta $=$ FPE $\&$ browserRok $=2012 \&$ browserPro-gram $=$ $921 \&$ browserObor $=2510 \&$ browserPlan $=10529 \&$ plang=en.

[15] Visual study programme of Informatics in Education [online]. Version A7, year 2011. Jan Evangelista Purkyně University in Ústí nad Labem. [Cit. 2012-07-10]. Available (in English) from https://portal.ujep.cz/StagPortletsJSR168/ CleanUrl? urlid=prohlizeni-browser-vizualizace \&browserFakulta $=$ PRF \&browserRok $=2012 \&$ browserProgram $=326 \&$ browserObor $=949 \&$ browserPlan $=5952 \&$ plang $=$ en .

[16] Visual study Programme of Informatics for Education [online]. Version 10, year 2012. Technical University of Liberec. [Cit. 2012-0710]. Available (in English) from https://stagnew.tul.cz/stag?urlid=prohlizeni-browservizualizace $\&$ browserFakulta $=$ FP\&browserRok $=$ 2012\&browserProgram $=1051 \&$ browserObor $=$ $2784 \&$ browserPlan=8639\&plang=en.

[17] Visual study programme of Informatics for Future Teachers [online]. Version 1, year 2012. University of South Bohemia in České Budějovice. [Cit. 2012-07-09]. Available (in English) from http://wstag.jcu.cz/StagPortlets JSR168/CleanUrl? urlid=prohlizeni-browservizualizace \&browserFakulta=FBI\&browserRok $=$ 2012\&browserProgram $=767 \&$ browserObor= $1544 \&$ browserPlan $=7235 \&$ plang $=$ en .

[18] Visual study programme of Information Technology in Education [online]. Version 1, year 2012. University of South Bohemia in České Budějovice. [Cit. 2012-07-09]. Available (in English) from http://wstag.jcu.cz/StagPortlets JSR168/CleanUrl?urlid=prohlizeni-browservizualizace \&browserFakulta=FPE\&browser Rok $=2012 \&$ browserProgram $=606 \&$ browserObor $=1449 \&$ browserPlan $=7535 \&$ plang $=$ en .

[19] Visual study programme of IT Education for Secondary Schools [online]. Version 11, year 2012. Tomas Bata University in Zlín. [Cit. 201207-09]. Available (in English) from 
http://portal.utb.cz/ stag?urlid=prohlizenibrowser-vizualizace \&browserFakulta=FAI $\&$ browserRok $=2012 \&$ browserProgram $=691 \&$ browserObor $=1606 \&$ browserPlan $=6573 \&$ plang $=$ en.

[20] Visual study programme of IT in Education [online]. Version 1, year 2012. University of West Bohemia in Plzeň. [Cit. 2012-07-10]. Available (in English) from https://portal.zcu.cz/ stag?urlid=prohlizeni-browser-vizualizace

\&browserFakulta $=\quad$ FPE\&browserRok $=2012 \&$ browserProgram $=905 \&$ browserObor $=2437 \&$ browserPlan $=10458 \&$ plang $=$ en .

[21] Visual study programme of SS Teacher Training in Computer Technology [online]. Verze 1, rok 2012. Version 1, year 2012. University of West Bohemia in Plzeň. [Cit. 201207-10]. Available (in English) from https://portal.zcu.cz/stag? urlid= prohlizenibrowser-vizualizace \&browserFakulta=FPE \& browserRok $=2012 \&$ browserProgram $=922 \&$ browserObor $=2525 \&$ browserPlan $=10552 \&$ plang $=$ en.

[22] Visual study programme of Teacher Training for Lower-Secondary School. Subject Informatics [online]. Version 12, year 2012. Technical University of Liberec. [Cit. 2012-0815]. Available (in English) from https://stagnew.tul.cz/stag?urlid= prohlizeni-browservizualizace \&browserFakulta $=$ FP\&browserRok= 2012\&browserProgram $=1042 \&$ browserObor= $2849 \&$ browserPlan=8993\&plang=en .
[23] Visual study programme of Teacher Training for Lower-Secondary and UpperSecondary School. Subject Informatics [online]. Version 12, year 2012. Technical University of Liberec. [Cit. 2012-08-15]. Available (in English) from https://stag-new.tul.cz/stag?urlid= prohlizeni-browser-vizualizace\&browserFakulta $=$ FP\&browserRok $=2012 \&$ browserProgram $=1043$ \&browserObor=2850\&browserPlan=8994\&plang $=$ en.

[24] Visual study programme of Teacher Training in Information Technology [online]. Version 1, year 2012. University of South Bohemia in České Budějovice. [Cit. 2012-07-09]. Available (in English) from http://wstag.jcu.cz/ StagPortletsJSR168/CleanUrl?urlid=prohlizenibrowser-vizualizace \&browserFakulta $=$ FPE $\&$ browserRok $=2012 \&$ browserProgram $=574 \&$ browserObor $=1470 \&$ browserPlan $=7698 \&$ plang=en.

\author{
Mgr. Jan Berki \\ Katedra aplikované matematiky \\ Fakulta přírodovědně-humanitní a \\ pedagogická \\ Technická univerzita v Liberci \\ Voroněžská 13 \\ 46001 Liberec, ČR \\ Tel: +420 485352304 , \\ E-mail: jan.berki@tul.cz \\ Www pracoviště: kap.fp.tul.cz
}

